\title{
VARIATIONS IN THE PERMEABILITY OF THE RED BLOOD CELLS IN MAN, WITH PARTICULAR REFERENCE TO THE CONDI- TIONS OBTAINING IN PERNICIOUS ANEMIA
}

\author{
By OLE BANG AND SøREN L. ØRSKOV \\ (From the Medical Department III, Kommunehospitalet, and the Institute for Medical \\ Physiology, University of Copenhagen, Copenhagen, Denmark)
}

(Received for publication November 4, 1936)

Man, as is well known, is one of the few species whose blood cells are permeable to glucose. The permeability rate of human blood cells for glucose has been the subject of many investigations attempting to define the significant factors of this phenomenon. Ege (1) was the first to investigate the importance of the concentration of the glucose. With a low glucose concentration there rapidly occurred a balance between the glucose in the extracellular fluid and the watery phase of the blood cells; with a higher degree of concentration, the blood cells gradually became swollen, with a much slower inward diffusion rate (a contributing factor here, however, was a probable simultaneous outward flow of potassium from the blood cells).

These conditions were more thoroughly examined by Bjering (2) who likewise found the rate of diffusion slower when the concentration of glucose was raised. He noted further that the diffusion rate for glucose gradually diminished to a degree greater than might be expected from Fick's law ${ }^{1}$ as more glucose entered the blood cells. There is much to suggest that it is a question of a tightening of the pores of the blood cell membranes in the presence of glucose molecules, as a similar lowering of the diffusion rate has been observed when collodium membranes are employed.

Bjering showed too that the inward flow of the glucose could be brought to a complete standstill by the addition of cyanide of mercury to the sus-

1 Fick's law accounts for the rate of diffusion through membranes by the formula:

$$
k \cdot t=\log \frac{C_{y}}{C_{y}-C_{i}},
$$

when $k$ is the constant, $t$ the time, $C_{y}$ the concentration of the investigated substance in the outer fluid, and $C_{3}$ the concentration of the substance in the watery phase inside the cell membrane. pension fluid. This same worker also investigated the importance of the temperature. He found a $Q_{10}{ }^{2}$ value of about 2, working with temperatures between $20^{\circ}$ and $30^{\circ} \mathrm{C}$., a reading corresponding to that found by Ørskov (3) for glycerin and thio-urea.

Investigations relating to the individual variations in the permeability of the blood cells from different persons are few in number. Schi $\phi \mathrm{dt}$ (4), who has devised a formula for the estimation of the permeability constant by hematocrit estimation, found a uniform constant in relation to the permeability to $\mathrm{NH}_{4} \mathrm{Br}$ in a series of normal men. He noted that the time interval during which the blood had stood prior to the performance of the test was a matter of importance, for example, older blood showed a lower permeability rate.

Schönheyder (5), using Schiødt's equation and the hematocrit method, tested the permeability constant of the blood cells for malonamid in $\mathbf{5 0}$ healthy and sick persons, and found a like constant in all the cases. The patients examined included various types of anemia, one case of pernicious anemia and one of hemolytic jaundice. No mention is made of the importance of the time interval during which the blood had stood before the performance of the tests. The experiments conducted by Jacobs (7) and by Höber and $\emptyset$ rskov (8), concerning the lapse of time before hemolysis took place in a suspension of human blood in solutions of different anelectrolytes were few in number. Furthermore, hemolytic tests are more uncertain than the determination of the permeability by the alterations in cell volume, so that their experiments perhaps bear no very great weight upon the subject in question.

Thus the literature to date affords no sure evi-

${ }^{2} Q_{10}$ stands for the increase in diffusion rate which is brought about by a rise in temperature of $10^{\circ} \mathrm{C}$. 
dence of a variation in the permeability of the blood cells from different persons.

Ørskov's experiments (6), however, establish the fact that there are considerable differences in the permeability to glycerin exhibited by the blood cells of different rabbits, while the permeability to thio-urea is more or less constant. It therefore seemed possible that the conditions relating to ammonium bromide and malonamid in the case of human beings might resemble those for thiourea in rabbits, and that one might succeed in finding substances exhibiting individual variations in permeability rate towards the blood cells of different persons, similar to that shown for glycerin in the case of rabbits' blood cells.

Tentative investigations revealed a variation from person to person in the diffusion rate for glucose through their respective blood cell membranes. The technique followed, of which an account has been given in a previous communication (3), was the same as that employed in corresponding experiments with rabbits' blood. Concerning the principle of the method, the technique, and the determination of the permeability constant, reference may be made to the publication in question. Here we shall only mention certain details.

The blood to be used is taken from a vein in the arm, defibrinated in a small closed test tube and filtered. The test is first made after a lapse of 4 hours or more, $1 \mathrm{cc}$. of blood being carefully suspended in $100 \mathrm{cc}$. of a 0.88 per cent $\mathrm{NaCl}$ and 0.15 per cent $\mathrm{NaHCO}_{3}$ solution, which is in equilibrium with oxygen that contains 4.7 per cent $\mathrm{CO}_{2}$ and has therefore a $\mathrm{pH}$ value of 7.3.

The container, in which the permeability rate is estimated, is large enough to hold $30 \mathrm{cc}$. of the suspension. The glucose solution employed is 2 molar (it contains also 0.9 per cent $\mathrm{NaCl}$ ), $1 \mathrm{cc}$. being taken for mixing with the blood cell suspension, so that this latter eventually contains 1.16 per cent glucose. For the purpose of gauging the permeability curve, adjustment curves are charted showing the effect of adding $1 \mathrm{cc}$. of 3.97 per cent saline solution to fresh samples of the blood cell suspension, whereby the osmotic pressure is raised half as much as with the addition of the glucose solution. In this manner the time required for the concentration of the glucose in the watery phase of the blood cells to reach half of that found in the extracellular fluid is determined.

In the following pages the permeability rate is expressed as the minute constant $(M-C),{ }^{3}$ which is calculated according to Fick's law. A number of tests were carried out for the purpose of defining which factors are those influencing the permeability.

As already stated, Ege's and Bjering's experiments showed that the concentration of the glucose plays a part in determining the rate of permeation. This was also the case in the experiments described below : the $M-C$ became less with a higher glucose concentration.

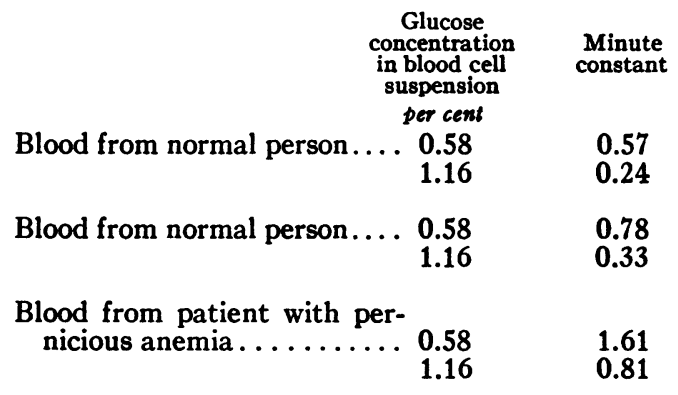

Thus it is seen that the permeability is raised 2.5 times, when the glucose concentration is halved.

In addition, the $Q_{10}$ of the blood from 3 persons, 2 of whom were suffering from pernicious anemia and one was normal, was determined. The variations in the temperature were produced by passing water at different temperatures through the spiral glass in the container holding the blood cell suspension.

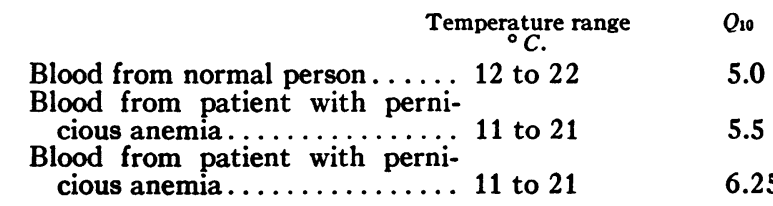

These experiments gave, therefore, a resulting $Q_{10}$ varying from 5.0 to 6.25 , i.e., values which are considerably higher than those obtained by Bjering. To ascertain if the reason for this divergence might lie in the utilization of different suspension fluids, a further series of tests was

3 The constant calculated from Fick's formula is called the minute constant $(M-C)$, when the time unit is one minute. A high $M-C$ reading corresponds with a rapid diffusion, a low $M-C$ reading with a slow diffusion. 
carried out with Christensen-Warburg's fluid," and the same $Q_{10}$ obtained as in the aforementioned experiments. Bjering used higher degrees of glucose concentration (2 to 4 per cent) than those employed in the above experiments, and it is possible that this factor may account for the considerable differences in the resulting readings.

The experiments recorded in this paper were performed at a temperature of about $20^{\circ}$, and the constants obtained have been corrected to $20^{\circ}$, being calculated for a $Q_{10}$ of 5.5 , except in those instances in which the $Q_{10}$ is directly estimated. The interval of time before the blood is used for the test undoubtedly plays a part in relation to the minute-constant; glucose diffuses through the blood cell membranes more readily when the blood employed is fresh than when it has stood for some hours. In the present series of experiments, the blood had stood for 4 hours or longer prior to its being used. After such an interval there occurs only very slight further alteration in the permeability judging from the few control tests performed. In this connection, however, there is a source of error, inasmuch as a control test was not performed in every case to determine how much the permeability had changed since the withdrawal of the sample or how much it might have changed if the blood had been allowed to stand for a still longer period.

The individual variations determined in the permeability to glucose, which were moreover much less than those shown in the case of glycerin and the blood from different rabbits, would have been more reliable if it had been possible in some way to stabilize the permeability of the blood cells immediately after the withdrawal of the blood. Preliminary tests, performed with this aim, did not, however, lead to any satisfactory result. Until further evidence is forthcoming, therefore, the best method of procedure without any doubt is to allow the blood to stand for so long a time that its permeability becomes more or less constant.

The permeability of the blood cells to glucose was investigated in 12 normal persons (Table I). The minute-constant here is seen to have varied within quite narrow limits, viz., 0.20 to 0.32 , giv-

4 Christensen-Warburg's fluid contains 11.5 grams $\mathrm{Na}_{2}(\mathrm{COO})_{2}, 0.315$ gram $\mathrm{KH}_{2} \mathrm{PO}_{4}$, and 1.365 grams $\mathrm{Na}_{2} \mathrm{HPO}_{4}$ per liter.
TABLE I

Normal persons

\begin{tabular}{|c|c|c|c|}
\hline $\begin{array}{c}\text { Case } \\
\text { number }\end{array}$ & Sex & Age & Glucose $M-C$ \\
\hline $\begin{array}{r}3 \\
11 \\
12 \\
27 \\
30 \\
38 \\
63 \\
132 \\
133 \\
134 \\
135 \\
136\end{array}$ & $\begin{array}{l}\mathbf{M} \\
\mathbf{M} \\
\mathbf{M} \\
\mathbf{M} \\
\mathbf{M} \\
\mathbf{F} \\
\mathbf{M} \\
\mathbf{M} \\
\mathbf{M} \\
\mathbf{M} \\
\mathbf{M} \\
\mathbf{M}\end{array}$ & $\begin{array}{c}\text { years } \\
20 \\
29 \\
35 \\
20 \\
69 \\
12 \\
8 \\
34 \\
21 \\
23 \\
22 \\
21\end{array}$ & $\begin{array}{l}0.30 \\
0.26 \\
0.32 \\
0.20 \\
0.20 \\
0.24 \\
0.32 \\
0.31 \\
0.24 \\
0.29 \\
0.29 \\
0.27\end{array}$ \\
\hline Total 12 & & $\begin{array}{l}\text { Average } \\
\text { Maximum } \\
\text { Minimum }\end{array}$ & $\begin{array}{ll} & 0.27 \\
\text { Im } & 0.32 \\
& 0.20\end{array}$ \\
\hline
\end{tabular}

ing an average of 0.27 . In 2 normal persons the permeability was tested at intervals of some days (Table II) and showed only small divergences

TABLE II

Normal persons on different days

\begin{tabular}{clc}
\hline \hline $\begin{array}{c}\text { Case } \\
\text { number }\end{array}$ & \multicolumn{1}{c}{ Date } & Glucose M-C \\
\hline 12 & December 13 & 0.33 \\
& December 17 & 0.30 \\
& April 4 & 0.33 \\
& Average & 0.32 \\
& January 10 & 0.35 \\
& March 4 & 0.30 \\
& March 4 & 0.28 \\
& March 9 & 0.28 \\
& March 10 & 0.31 \\
& March 11 & 0.32 \\
& March 16 & 0.30 \\
& Average & 0.31 \\
\hline
\end{tabular}

from the average in these same, namely, a maximal variation of plus 0.04 and minus 0.03 , i.e., roughly 13 per cent.

The alteration in the permeability of rabbits' blood cells to glycerin after venesection, shown by $\emptyset$ rskov (6), prompted the experiments recorded in Table III in relation to the permeability of the blood cells to glucose in the case of human beings in the regenerative stage after gastro-intestinal hemorrhage. In this series, the same average $M-C$ was found as in normal persons, viz., 0.27 . The range of variations on the other hand is seen to have been larger, namely, a maximal plus 0.12 and minus 0.12 . The variations do not appear to 
TABLE III

Posthemorrhagic anemia

\begin{tabular}{|c|c|c|c|c|c|}
\hline $\begin{array}{c}\text { Case } \\
\text { num- } \\
\text { ber }\end{array}$ & Diagnosis & $\begin{array}{l}\text { Hemo- } \\
\text { globin }\end{array}$ & $\begin{array}{c}\text { Red } \\
\text { blood } \\
\text { cells }\end{array}$ & $\begin{array}{l}\text { Color } \\
\text { index }\end{array}$ & $M-C$ \\
\hline $\begin{array}{r}1 \\
4 \\
5 \\
5 \\
24 \\
26 \\
29 \\
37 \\
59 \\
70\end{array}$ & $\begin{array}{l}\text { Ulcer of duodenum; hematemesis; leu- } \\
\text { kopenia } \\
\text { Duodenitis; hematemesis } \\
\text { Hematemesis } \\
\text { Ulcer of duodenum; melena } \\
\text { Cirrhosis of liver; hematemesis } \\
\text { Ulcer of duodenum; hematemesis } \\
\text { Hematemesis } \\
\text { Ulc. ventriculi } \\
\text { Hemorrhoid tumor; melena }\end{array}$ & $\begin{array}{c}\text { per cent } \\
41 \\
64 \\
95 \\
48 \\
37 \\
59 \\
41 \\
34 \\
41\end{array}$ & \begin{tabular}{|l} 
million \\
2.1 \\
3.3 \\
4.75 \\
2.5 \\
2.7 \\
2.7 \\
2.1 \\
1.9 \\
3.5
\end{tabular} & $\begin{array}{l}1.0 \\
1.0 \\
1.0 \\
1.0 \\
0.7 \\
1.1 \\
1.0 \\
0.9 \\
0.6\end{array}$ & $\begin{array}{l}0.39 \\
0.26 \\
0.24 \\
0.20 \\
0.28 \\
0.24 \\
0.15 \\
0.35 \\
0.35\end{array}$ \\
\hline $\begin{array}{c}\text { Total } \\
9\end{array}$ & & & & $\begin{array}{l}\text { verage } \\
\text { Iaximum } \\
\text { linimum }\end{array}$ & $\begin{array}{l}0.27 \\
0.39 \\
0.15\end{array}$ \\
\hline
\end{tabular}

stand in any dependent relationship to the degree of anemia.

Thus a minute-constant of 0.40 or over was not found in association with posthemorrhagic anemia. This figure too is much above that of the readings obtained from normal persons. A minute-constant above 0.40 was, however, regularly noted in cases of untreated pernicious anemia, such as will be described in greater detail in the subsequent pages. It was a matter of interest therefore, to ascertain if similar conditions in relation to the permeability are present in other conditions. The provisional observations from such an investigation are recorded in Table IV, from which it is seen that in the large majority of the patients examined the $M-C$ was below 0.40 and in most instances within the range of the readings obtained from normal persons. (A point of special interest was the finding of normal values in 2 cases of leukemia, Cases 42 and 43.)

An increased permeability to glucose, i.e., $M-C$ over 0.40 was found in 2 patients. The one case, Number 28, was that of an osteitis deformans (particularly of the pelvic bones) complicated by a mild degree of anemia with hemoglobin 89 per cent, red blood cells 4 million. Here the $M-C$ persisted practically unaltered, while the anemia was cured with iron (hemoglobin 99 per cent, red blood cells 5.07 million). The other case, Number 50 , concerned a young man with diabetes in whom the control of the blood sugar presented certain difficulties. In this patient it was not possible to define the presence of any other abnormality, particularly no anemia. However, in two other cases of diabetes, Numbers 21 and 35, we obtained normal readings of the $M-C$ for glucose.
The maximal variation between two tests from the same individual performed at different times (Table II) amounted to 25 per cent of the lowest values read. Among the 12 normal persons ( $\mathrm{Ta}$ ble I) the greatest variation was one of 60 per cent of the lowest reading, and among the cases of posthemorrhagic anemia (Table III) one of 160 per cent. If the patients with miscellaneous diseases be considered, apart from the two cases mentioned above in which the $M-C$ was above 0.40 , the maximal difference in this group was one of 124 per cent. The wide divergences seen in Tables III and IV certainly cannot be explained as technical errors, but must be interpreted either as individual variations or as alterations of permeability occasioned by disease. With regard to the smaller variations to be noted in Table I the question as to whether we have to take individual differences into account must for the present remain undecided.

In contrast with the conditions obtaining in simple posthemorrhagic anemia we found, as stated, a strikingly increased permeability of the red cells from untreated cases of pernicious anemia. From Table $\mathrm{V}$ it is evident that in all 4 cases the $M-C$ was increased, ranging from 0.42 to 1.14 and with an average of 0.82 , while the patients with posthemorrhagic anemia, as well as the normal persons, presented a $M-C$ averaging 0.27 with a

TABLE IV

Miscellaneous

\begin{tabular}{clc}
\hline \hline $\begin{array}{c}\text { Case } \\
\text { num- } \\
\text { ber }\end{array}$ & \multicolumn{1}{c}{ Diagnosis } & $\begin{array}{c}\text { Glucose } \\
M-C\end{array}$ \\
\hline 7 & Hypertonia; meningeal hemorrhage & 0.19 \\
17 & Hepatitis acute & 0.28 \\
18 & Hyperthyroidism & 0.33 \\
21 & Diabetes mellitus & 0.20 \\
28 & Osteitis deformans & 0.42 \\
31 & Pneumonia & 0.21 \\
32 & Undulant fever & 0.20 \\
33 & Chorea & 0.22 \\
34 & Arthritis; anemia & 0.18 \\
35 & Diabetes mellitus & 0.26 \\
36 & Gastritis & 0.30 \\
42 & Acute myeloid leukemia; anemia & 0.23 \\
43 & Acute myeloid leukemia; anemia & 0.30 \\
48 & Hypothyroidism; anemia; epilepsy & 0.26 \\
$50 a$ & Diabetes mellitus prior to insulin & 0.51 \\
$50 b$ & Diabetes mellitus after insulin, on same day & 0.51 \\
50 c & Diabetes mellitus after insulin, 9 days later & 0.44 \\
51 & Cirrhosis of liver; anemia & 0.21 \\
60 & Sequelae to thrombopenia & 0.38 \\
62 & Chronic nephritis; puerperium; anemia & 0.32 \\
65 & Morbus cordis; hypertonia; anemia & 0.19 \\
97 & Acute hepatitis & 0.17 \\
\hline & & \\
\hline
\end{tabular}


maximal reading of 0.39 . The rise in the permeability is seen to stand in no simple relationship to the degree of the pernicious anemia as expressed by the hemoglobin percentage, red cell count and color index. Thus the highest $M-C$ reading was 1.14 and the lowest 0.42 , with about the same degree of anemia in each case, viz., respective hemoglobin percentages of 37 and 35 and red cell count of 1.45 and 1.33 million.

TABLE V

Pernicious anemia untreated

\begin{tabular}{|c|c|c|c|c|}
\hline $\begin{array}{c}\text { Case } \\
\text { number }\end{array}$ & $\begin{array}{l}\text { Hemo- } \\
\text { globin }\end{array}$ & $\begin{array}{l}\text { Red blood } \\
\text { cells }\end{array}$ & $\begin{array}{l}\text { Color } \\
\text { index }\end{array}$ & $\underset{M-C}{\text { Glucose }}$ \\
\hline $\begin{array}{r}2 \\
15 \\
88 \\
100\end{array}$ & $\begin{array}{c}\text { per cent } \\
72 \\
37 \\
23 \\
35\end{array}$ & $\begin{array}{c}\text { million } \\
2.65 \\
1.45 \\
0.74 \\
1.33\end{array}$ & $\begin{array}{l}1.35 \\
1.28 \\
1.55 \\
1.32\end{array}$ & $\begin{array}{l}0.92 \\
1.14 \\
0.81 \\
0.42\end{array}$ \\
\hline Total 4 & & & $\begin{array}{l}\text { Average } \\
\text { Maximum } \\
\text { Minimum }\end{array}$ & $\begin{array}{l}0.82 \\
1.14 \\
0.42\end{array}$ \\
\hline
\end{tabular}

In the other 6 cases of pernicious anemia ${ }^{5}$ the permeability tests were performed after the commencement of specific treatment (Table VI).

TABLE VI

Pernicious anemia during treatment

\begin{tabular}{|c|c|c|c|c|}
\hline $\begin{array}{c}\text { Case } \\
\text { number }\end{array}$ & $\begin{array}{l}\text { Hemo- } \\
\text { globin }\end{array}$ & $\begin{array}{l}\text { Red blood } \\
\text { cells }\end{array}$ & $\begin{array}{l}\text { Color } \\
\text { index }\end{array}$ & $\underset{M-C}{\text { Glucose }}$ \\
\hline $\begin{array}{r}8 \\
9 \\
23 \\
44 \\
46 \\
49\end{array}$ & $\begin{array}{c}\text { per cent } \\
76 \\
82 \\
70 \\
81 \\
81 \\
46\end{array}$ & $\begin{array}{c}\text { million } \\
3.1 \\
4.0 \\
2.9 \\
\\
4.1 \\
1.5\end{array}$ & $\begin{array}{l}1.23 \\
1.02 \\
1.21 \\
\\
0.99 \\
1.53\end{array}$ & $\begin{array}{l}0.81 \\
0.21 \\
0.46 \\
0.20 \\
0.48 \\
0.72\end{array}$ \\
\hline Total 6 & & & $\begin{array}{l}\text { Average } \\
\text { Maximum } \\
\text { Minimum }\end{array}$ & $\begin{array}{l}0.48 \\
0.81 \\
0.20\end{array}$ \\
\hline
\end{tabular}

Two of these gave the normal readings $(M-C 0.20$ and 0.21 ) and in the remaining 4 cases an increased reading ( $M-C 0.46$ to 0.81 ). In these 6 patients, just as in the untreated cases, no definite parallelism was found between the degree of anemia and the value of the permeability read.

\footnotetext{
5 We offer our thanks to Dr. K. H. Krabbe, Physicianin-charge of the Department for Nervous Diseases, Kommunehospital, for the opportunity to examine Cases 44, 46 and 49.
}

The observation that two of these patients exhibited normal permeability suggests that the specific treatment was responsible for the effect. More detailed information on this point is furnished by the accompanying curves which show the course of the anemia and of the permeability during treatment.

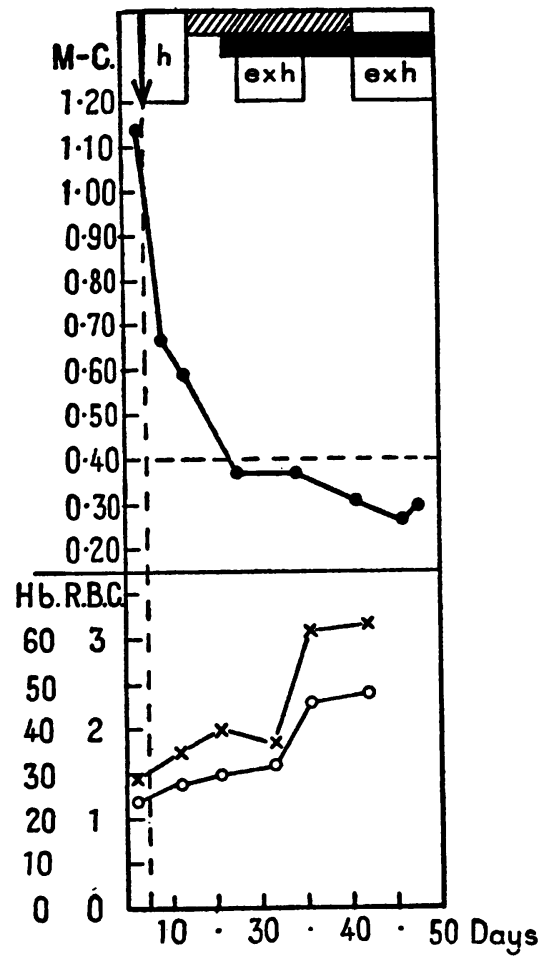

Fig. 1. Case 15 (Table V). Nor Previously Treated.

Treatment. Hepsol 4 cc. daily intramuscularly (h); tonicum "DAK" 10 cc. t.d. (hatched); exhepa 1 dose t.d. (exh.), reduced iron 0.5 gram t.d. (solid black).

The upper curve in each Figure indicates the $M-C$ drawn - the lower curve the hemoglobin percentage shown by $X-X$, the red-cell count in millions $\mathrm{O}-\mathrm{O}$, and the reticulocyte percentage $\mathbf{0 . . .}$; the commenceinent of the specific treatment is indicated by an arrow. The abscissae show the number of days after admission to hospital.

Characterizing these curves is the pronounced decrease in the permeability readings which assumed entirely normal values during the treatment in every case.

This decrease, however, is lacking in Figure 5. This patient had been undergoing treatment over a long period prior to admission. In this instance the permeability rate was normal from the beginning of the examination and continued so. 


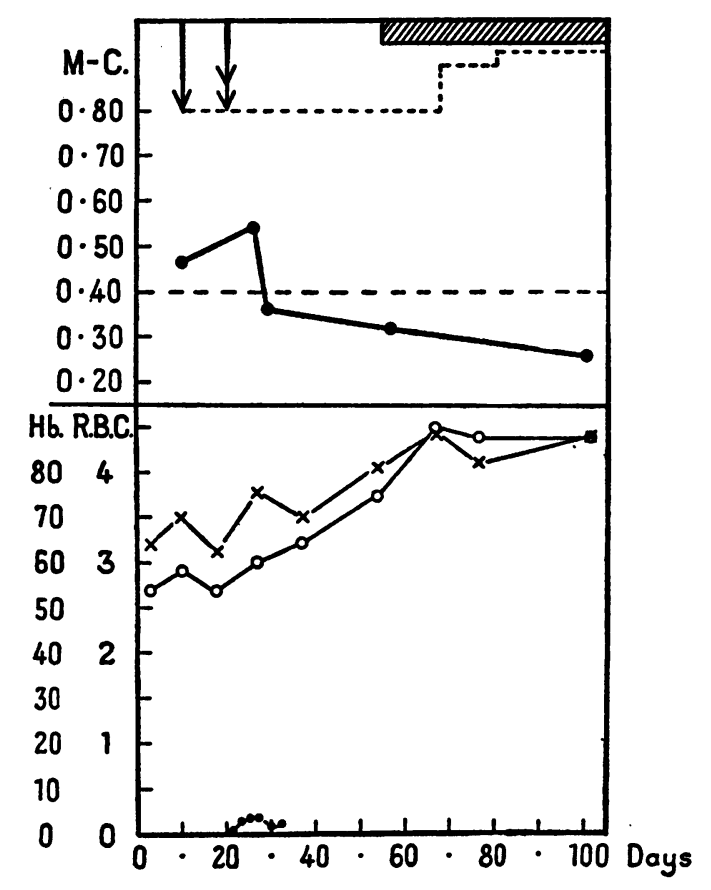

Fig. 2. Case 23 (Table VI).

Until just before admission to hospital the patient had been receiving liver by mouth and by injections.

Treatment. Hepsol $4 \mathrm{cc}$. daily (from single to double arrow); campolon 2 cc. daily, later every second and third day (from double arrow); pylorin 10 grams t.d. (hatched).

Further, it is to be noted that the permeability returned to normal in all the cases where there was still a definite and in most instances a considerable degree of anemia present. In these preliminary experiments it has not been possible to carry out observations over any length of time during the untreated stage of the disease. The fall in the $M-C$ value before treatment, seen in Figures 6 and 7, is so small that it is not necessarily a genuine one. The possibility, however, cannot be excluded that rest in bed and the hospital diet among other factors may have had some action upon the permeability. In Figure 6 the permeability curve shows a gradual regular fall from values bordering on the normal to completely normal readings. Figure 7 on the other hand shows a sharp acceleration in the fall of the permeability immediately after the beginning of treatment. Since a similar fall occurs in Figures 1 and 3 , it may be maintained with some conviction that the fall was dependent upon the specific treatment.
In Figure 7, there occurs a depression upon the permeability curve corresponding to the rise in the number of reticulocytes. It is possible that the reticulocytes, amounting in this instance to 49 per cent of the circulating blood cells, are cells with a particularly low permeability to glucose. No weight, however, can be placed upon this observation unless it be possible to reproduce it.

Tests were conducted in relation to the permeability rate for glycerin, thio-urea and malonamid in fewer instances than the estimations of the permeability rate for glucose. In spite of the small amount of material investigated, these tests furnished very interesting observations, so that we shall therefore give a short account of the result obtained.

With regard to glycerin it was noted that the permeability rate was lower in pernicious anemia than in normal persons and that the administration of liver did not produce any alteration in the rate (one case only examined, Case 15, Figure 1, in which, however, there was observed a striking effect upon the permeability rate for glucose). A

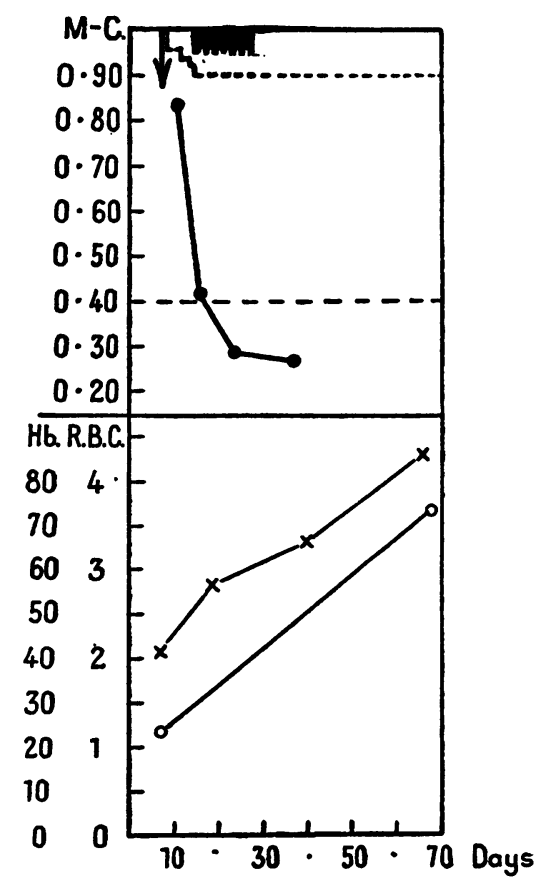

Fig. 3. Case 49 (Table VI). Not Previously TREATED.

Treatment. Pylorin 10 grams once daily (from arrow); hepsol $4 \mathrm{cc}$. increasing to $10 \mathrm{cc}$. daily (stippled); betaxin $2 \mathrm{cc}$. on alternate days (solid black). 
certain degree of conformity was shown in a series of cases between the permeability rates for thio-urea and for glucose. Concerning thio-urea there were noted quite large individual variations which in their broad features resembled those ob-

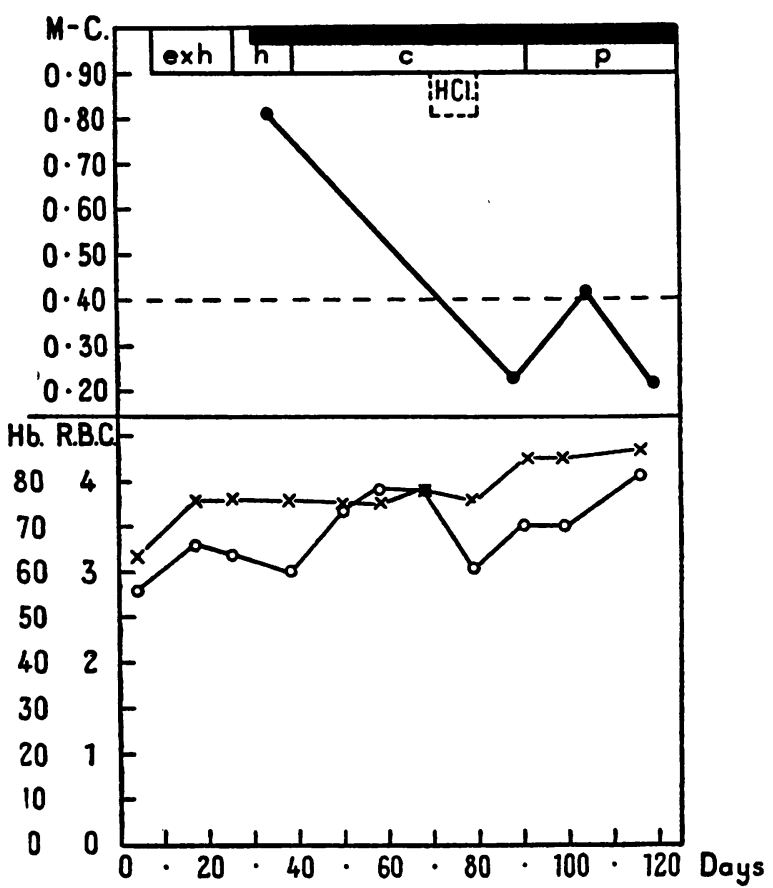

Fig. 4. Case 8 (Table VI). Treated with Liver for about 12 Months up to the Time of Admission.

Treatment. Exhepa 1 dose t.i.d. (exh.); hepsol 4 cc. daily (h); campolon 2 cc. daily (c); pylorin 10 grams b.i.d. (p); reduced iron 0.5 gram t.d. (solid black); hydrochloric acid 20 drops t.d. $(\mathrm{HCl})$.

served for glucose. Two cases of pernicious anemia showed at first a permeability rate for thiourea which was twice as high as the normal figure, a difference which disappeared during the course of treatment.

Concerning malonamid a series of patients exhibited a constant permeability rate showing a deviation of less than 10 per cent from the average reading. Two cases of pernicious anemia with an increased permeability to glucose were studied, and an increased permeability rate for malonamid was found. In the one patient (Case 23, Table VI, Figure 2) the increase was one of 15 per cent above the previously mentioned average value, and in the second case (Number 15, Table V, Figure 1) an increase of 42 per cent. This latter case exhibited a normal permeability rate at the end of 20 days' treatment.

In our series of cases of pernicious anemia, the diagnosis rested upon the general examination and the blood picture, supplemented by repeated test meals, as well as by the reaction to specific treatment (in Case 8, Figure 4, and Case 9, Figure 5, this reaction was confirmed by the response shown during previous admissions to hospital). Marked paresthesia was exhibited by Cases $8,9,23,88$ and 100 , and characteristic myelopathies were noted in Cases 23, 44 and 49. In Case 15, Figure 1, x-ray examination revealed changes in the stomach which might be interpreted as a carcinoma of the pylorus. The pernicious anemia in this case must therefore be regarded as having been probably complicated-if not occasioned-by a carcinoma of the stomach. The patient has since died from cachexia with severe ascites (no autopsy).

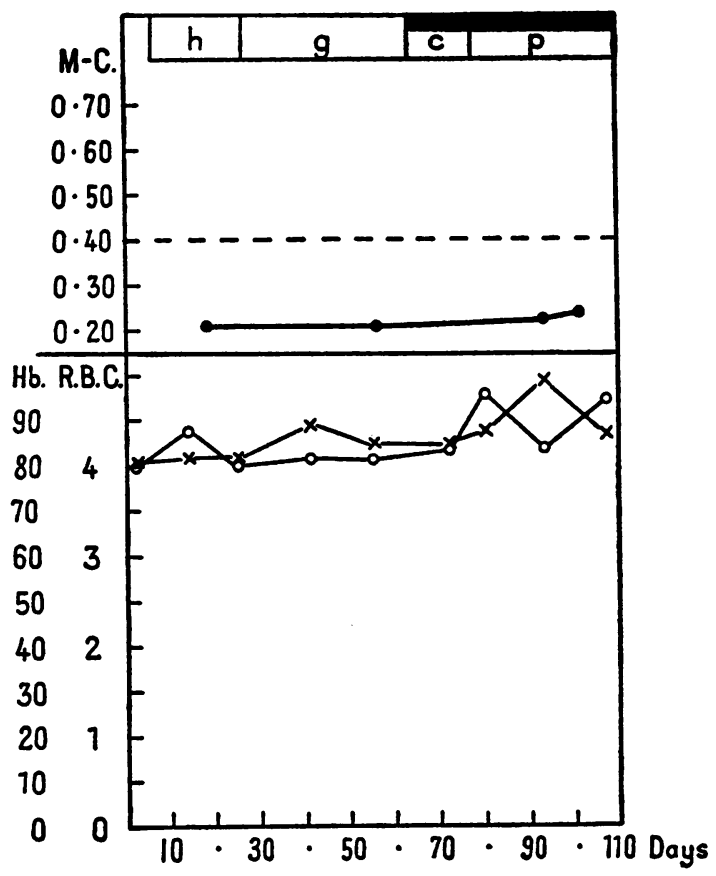

Fig. 5. Case 9 (Table Vi). Treated with VentricuLIN UNTIL ADMISSION.

Treatment. Hepsol (h) ; Ext. hepatis "GEA" (g) ; campolon (c); pylorin (p); iron (solid black).

In making any attempt to explain the increased permeability of the blood cells in pernicious anemia (to glucose, malonamid and thio-urea) we stand upon very uncertain ground. The size of the blood cells does not explain the increased 
permeability. As is evident from the color index and from Price-Jones' curves the number of microcytes is small in relation to the number of very large blood cells. These latter must therefore be expected to control entirely the permeability rate, and since the thickness of these same cells is probably not less than that of normal cells, the glucose and 7), namely, the changes in the permeability at a point of time when the therapeutic action upon the hemoglobin percentage, the number of red cells and reticulocytes was still comparatively slight. If this be the correct explanation, one is led to correlate other symptoms of pernicious anemia also with an altered condition of the per-

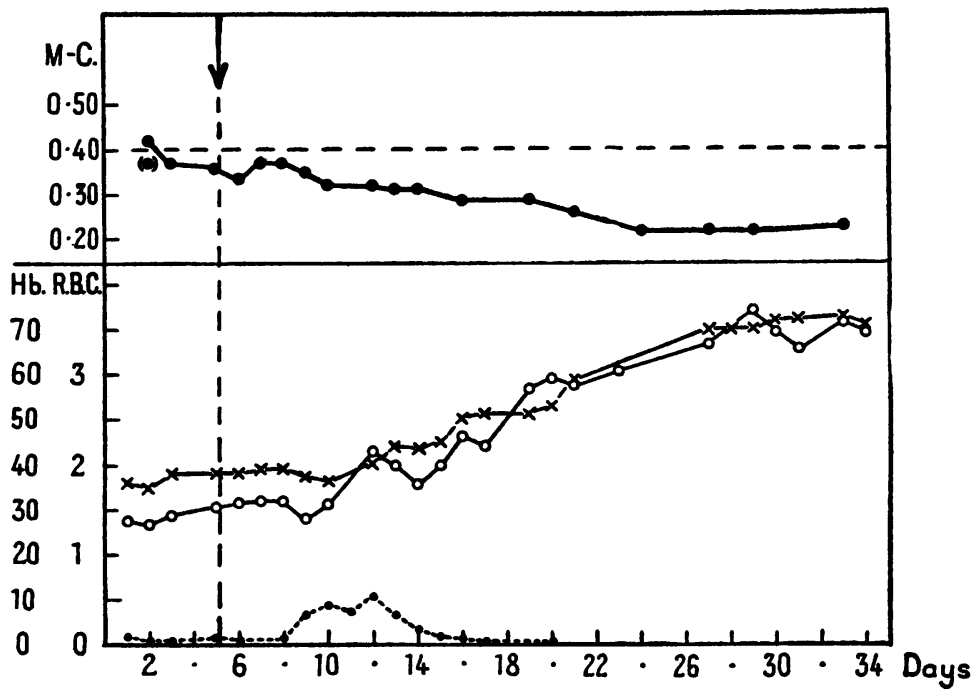

Fig. 6. Case 100 (Table V). Not Previously Treated.

Treatment. From arrow onwards-Exhepa fortior "Ferrosan" $4 \mathrm{cc}$. daily.

within these blood cells has the same or a greater distance to traverse in comparison with the conditions present in normal blood cells, a circumstance which cannot give rise to an increased permeability. Moreover, the observation that glycerin, practically speaking, permeates more slowly into the blood cells from cases of pernicious anemia shows that the explanation cannot be so simple. One is therefore forced to assume that the structure or the function of the cell membrane is of a peculiar quality in pernicious anemia.

To explain the changes noted during the course of treatment it is possible to consider: 1 , an alteration in the membrane of the blood cells in the circulating blood stream; 2 , an extensive formation of new blood cells with a low permeability; and 3 , a diminished destruction of blood cells with a consequent rise in the average age of the circulating blood cells.

In support of the first possibility was the extraordinarily rapid effect of the treatment upon the permeability noted in a few cases (Figures 1, 3 meability in different body tissues and thereby find a suitable interpretation of the strikingly rapid improvement of certain subjective symptoms often to be noted. The permeability of the circulating blood cells is increased in experimentally produced lead poisoning (Henriques and $\emptyset$ rskov (9)). Moreover, a certain analogy between lead poisoning and pernicious anemia may be seen in the fact that in both diseases, in addition to the established increase in permeability of the red blood cells, there may be found marked changes in the nervous system.

The assumption of an extensive and rapidly appearing formation of new blood cells having a low permeability meets with certain difficulties. The circumstance that the red cell count does not rise rapidly during the first few days following the commencement of treatment might thus seem to disprove any extensive formation of new blood cells, and the course of the reticulocyte curves suggests the same objection.

There are grounds, however, for supposing that 
the life of the blood cells in untreated pernicious anemia is considerably shorter than the normal. Thus Morawitz (10) observed a very considerable consumption of oxygen in such blood cells, similar to the consumption he had found in very young blood cells; and further, the markedly increased excretion of bile pigments, etc., shows that longed average life should result in a lowering of their permeability, is confronted with the same objections mentioned in reference to the second explanation above, namely, that the percentage of hemoglobin and the blood cell count do not show corresponding changes. The further assumption is required that the production of blood cells is

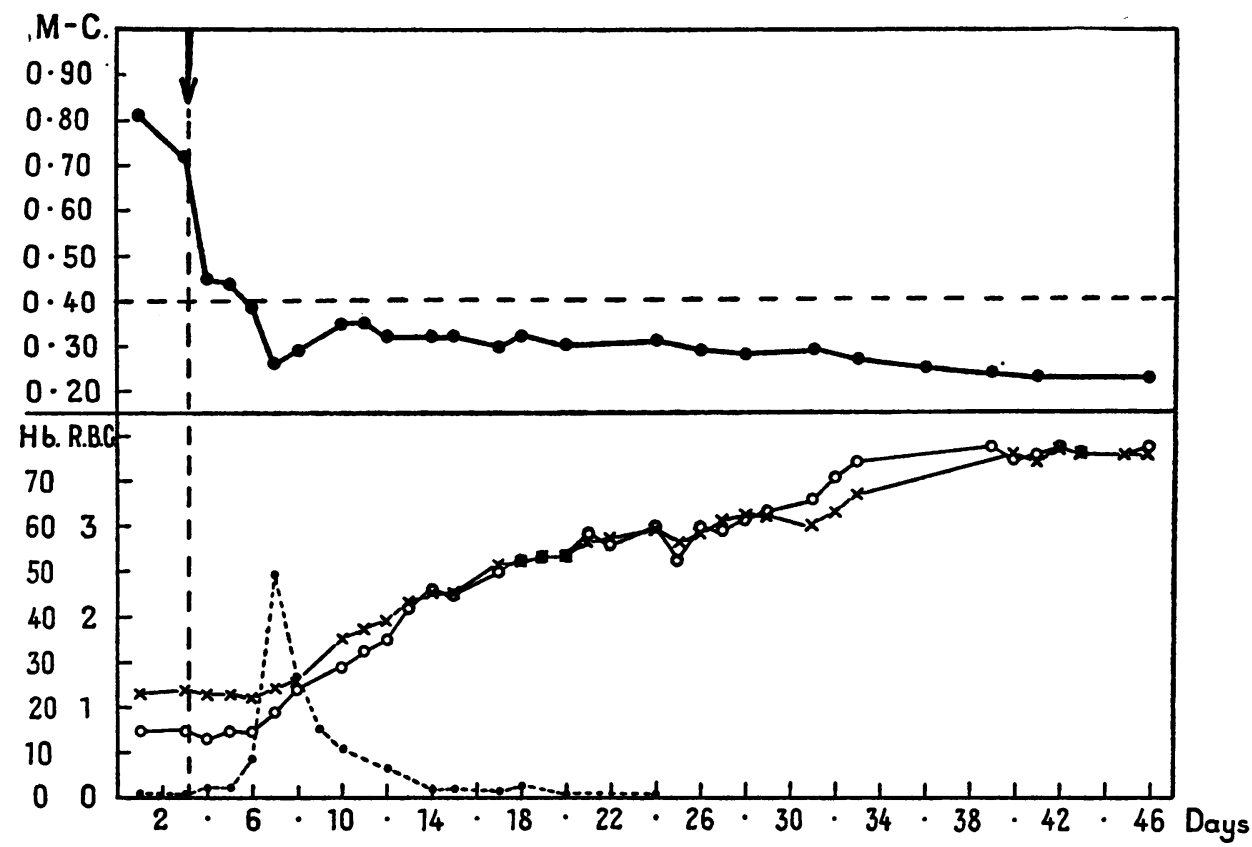

Fig. 7. Case 88 (Table V). No Regular Previous Treatment. Hardly Any Treatment at All During the Months Immediately Prior to Admission.

Treatment. From arrow onwards-pylorin 10 grams b.i.d. and campolon 2 cc. daily.

the destruction of blood cells is greater than that normally occurring. The reticulocytes too would seem to have a short life. ${ }^{\circ}$ If, for example, we assign a life of only 4 days to the blood cells in pernicious anemia, then as early as at the end of one day's treatment with liver we should be able to find 25 per cent of the blood cells exhibiting an altered permeability. Such a sequence of events is undoubtedly possible.

The hypothesis that an immediate result of the specific treatment is the occurrence of a diminished destruction of red cells, whereby their pro-

\footnotetext{
B In this connection, however, the attention may be drawn to our observation of a normal permeability to glycerin, while in rabbits a raised permeability to glycerin was a marked phenomenon in the newly formed blood cells following venesection. The explanation, however, may possibly lie in differences in the nature of the blood cell membranes.
}

also reduced, at any rate temporarily, during the first days of treatment. By adopting the supposition of an altered degree of destruction we are led back to the older theories concerning the pathogenesis of pernicious anemia, which assume an increased destruction of the blood cells as being the primary lesion.

The hypothesis that all young blood cells are more readily permeable to glucose is, however, hardly valid, since an increased permeability should then be also demonstrable in posthemorrhagic anemias, when the freshly formed blood cells must amount to a relatively large proportion of the total count. As is evident from Table III there is no suggestion of such a finding, so that it is necessary to add to the above hypothesis the conception of special conditions obtaining in the newly formed blood cells appearing in pernicious anemia. 


\section{SUM MARY}

The extent and nature of the variations in the permeability of the red blood cells in different individuals has been studied with special reference to their permeability to glucose. Some of the factors exerting an influence upon the permeability are examined in detail.

1. By increasing the concentration of glucose in the suspension fluid from 0.58 per cent to 1.16 per cent the permeability is reduced 2.5 times.

2. In the performance of the experiments in question the $Q_{10}$ was 5.0 to 6.25 .

3 . The variations in the normal permeability to glucose were found to exceed the limits of any technical error, being probably an expression of individual differences.

4. In posthemorrhagic anemias, comparatively large variations were noted without any relationship to the degree of the anemia, and no increased permeability was found.

5. Entirely similar variations were found in a series of miscellaneous diseases.

6. In one case of osteitis deformans and in one among three cases of diabetes a definitely increased permeability was noted.

7. Ten cases of pernicious anemia were examined. In 4 untreated cases, the permeability was markedly increased (to as much as 4 times the average normal reading), while the same conditions were noted in 4 out of 6 cases tested during the specific treatment.

8. In 7 cases of pernicious anemia the permeability was tested periodically during the course of treatment, during which it became normal in each case.

9. The effect of the specific treatment upon the permeability became demonstrable early and in 2 instances was noted to begin after 1 to 3 days' treatment. In all the cases, normal readings were obtained at a time when a high degree of anemia still persisted.
10. Individual examinations of the permeability to malonamid and to thio-urea yielded results similar to those observed in the case of glucose, while the permeability to glycerin was found to be normal in pernicious anemia, and to be unaffected by specific treatment.

11. The possible mechanism of the increased permeability in pernicious anemia and the effect of specific treatment are discussed.

\section{BIBLIOGRAPHY}

1. Ege, R., Studier over Glukosens Fordeling mellem Plasmaet og de røde Blodlegemer. Thesis. Copenhagen. 1919.

2. Bjering, T., Studier over Glukosens Indvandring $\mathrm{i}$ Menneskets r $\varnothing$ de Blodlegemer. Thesis. A. Busck, Copenhagen. 1932.

3. Ørskov, Søren L., Eine Methode zur fortlaufenden photographischen Aufzeichnung von Volumänderungen der roten Blutkörperchen. Biochem. Ztschr., 1935, 279, 241.

4. Schiфdt, E., Om Blodlegemers Permeabilitet. Thesis. A. Busck, Copenhagen, 1931.

5. Schönheyder, Fritz, Ubber die Permeabilität der roten Blutkörperchen für Malonamid. Skandinav. Arch. f. Physiol., 1934, 71, 39.

6. Ørskov, Søren L., Untersuchungen über individuelle Verschiedenheiten der Permeabilität der Kaninchenblutkörperchen und der Einfluss von Aderlass auf dieselbe. Biochem. Ztschr., 1937, 332. (In press.)

7. Jacobs, M. H., Osmotic hemolysis and zoological classification. Proc. Am. Philosoph. Soc., 1931, 70, 363.

8. Höber, R. and Ørskov, S $\phi$ ren L., Untersuchungen über die Permeiergeschwindigkeit von Anelektrolyten bei den roten Blutkörperchen verschiedener Tierarten. Arch. f. d. ges. Physiol., 1933, 231, 599.

9. Henriques, Vald. and Ørskov, Sфren L., Untersuchungen über die Schwankungen des Kationengehaltes der roten Blutkörperchen. II. Änderung des Kaliumgehalts der Blutkörperchen bei Bleivergiftung. Skandinav. Arch. f. Physiol., 1936, 74, 78.

10. Morawitz, P., Messung des Blutumsatzes. Handbuch der normal. und path. Physiol., 1928, 6, 203. 